\title{
First report of powdery mildew caused by Erysiphe polygoni on Rumex japonicus in Korea
}

\author{
In-Young Choi ${ }^{1} \cdot$ Hyun-Myung $\mathrm{Oh}^{1} \cdot$ Sun-Hee Hong ${ }^{2} \cdot$ Young-Ho Lee $^{2} \cdot$ Hyeon-Dong Shin $^{3}$ (D)
}

Received: 11 May 2020 / Accepted: 4 October 2021 / Published online: 15 October 2021

(c) Società Italiana di Patologia Vegetale (S.I.Pa.V.) 2021

Keywords Chamothecia $\cdot$ Noxious weed $\cdot$ Polygonaceae

Rumex japonicus, although indigenous to East Asia, is regraded as a noxious weed in Korea. In June and November 2017, powdery mildew was found on several plants growing wild in Hoengseong (disease incidence 100\%), and Mokpo (disease incidence 50\%), respectively. Symptoms first appeared as white mycelia on the lower leaves, and subsequently the leaves turned yellow and necrotic, and withered. Two isolates were deposited in the Korea University herbarium (KUS-F29825 and F30382). Lobed appressoria on the hyphae were solitary or in pairs. Conidiophores $(n=30)$ were erect, 70 to $146 \times 7$ to $9 \mu \mathrm{m}$, and composed of 3 to 4 cells. Foot-cells of conidiophores were cylindrical and 36 to $64 \mu \mathrm{m}$ long. Singly formed conidia $(n=30)$ were cylindricoval to oblong, 26 to $50 \times 14$ to $24 \mu \mathrm{m}$, and devoid of fibrosin bodies. Germ tubes arose from one end of the conidia. The morphological features of the fungus and the host genus are consistent with those of Erysiphe polygoni DC. (Braun and Cook 2012). Chasmothecia were not observed. To confirm the identification, the internal transcribed spacer (ITS) was amplified using the primer ITS1F and PM6, and PM3 and TW14 for the large subunit (LSU) of the rDNA. The resulting sequences were registered to GenBank (MT361079, MT361081 for ITS, MT361769 for LSU). A Blast'n search using the sequences showed $>99 \%$ similarities with E. ploygoni (LC328322, AF011308, MG647828, KY660827 for ITS and LC328322 for LSU). Infection of $R$. japonicus by E. polygoni has been known in Japan and China (Farr and
Rossman 2021). Although E. polygoni has been recorded on many host genera/species belonging to the Polygonaceae in Korea, this is the first report of E. polygoni on R. japonicus. Powdery mildew infections seem to suppress the growth and spread of this weed in natural habitat.

Acknowledgements This work was supported by Korea Institute of Planning and Evaluation for Technology in Food, Agriculture and Forestry (IPET) through Crop Viruses and Pests Response Industry Technology Development Program, funded by Ministry of Agriculture, Food and Rural Affairs (MAFRA) (Project No. 320043-05).

\section{Declarations}

Conflict of interest The authors declare no conflict of interest.

\section{References}

Braun U, Cook RTA (2012) Taxonomic manual of the Erysiphales (Powdery Mildews). CBS Biodiversity Series No. 11. CBS, Utrecht, The Netherlands

Farr DF, Rossman AY (2021) Fungal databases, syst. Mycol. Microbiol. Lab., Online publication. ARS, USDA. Retrieved May 4, 2021

Publisher's Note Springer Nature remains neutral with regard to jurisdictional claims in published maps and institutional affiliations.

Hyeon-Dong Shin

hdshin@korea.ac.kr

1 Department of Agricultural Biology, Jeonbuk National University, Jeonju 54896, Korea

2 Department of Plant and Environmental Science, Hankyong National University, Anseong 17579, Korea

3 Division of Environmental Science and Ecological Engineering, Korea University, Seoul 02841, Korea 